This is a postprint of: Wyatt, M. \& Dikilitaş, K. (2016). English language teachers becoming more efficacious through research engagement at their Turkish university. Educational Action Research, 24(4), 550-570. http://www.tandfonline.com/doi/pdf/10.1080/09650792.2015.1076731

\title{
English language teachers becoming more efficacious through research engagement at their Turkish university
}

\author{
Mark Wyatt, University of Portsmouth, UK \\ Kenan Dikilitaş, Hasan Kalyoncu University, Gaziantep, Turkey
}

\begin{abstract}
While it is generally recognised that teacher research can be a very beneficial form of continuing professional development (CPD), there is still relatively limited research available on the impact this activity has on teachers' selfefficacy beliefs, which are of interest to educational psychologists since, while being open to constant change, these beliefs influence the way that knowledge is transformed into action. There is also a relative lack of available research into how teachers develop as researchers; the processes whereby they gain practical knowledge and more positive self-efficacy beliefs in planning, conducting, analysing, presenting and writing up research require further exploration. This qualitative multi-case study addresses these issues, exploring the development of three in-service teachers of English on a foundation programme at a Turkish university. Findings reveal that engaging in CPD that directly benefited their learners helped all three teachers develop positive teachers' self-efficacy beliefs and deeper practical knowledge in relation to the specific tasks that concerned them. Furthermore, from a starting point of having low self-efficacy beliefs in conducting practical research, which reflected their lack of prior knowledge in this area, they all became more efficacious as they gained research experience and developed practical knowledge of research. This study highlights the benefits, then, of helping teachers become more efficacious through CPD that engages them as knowledge-generators. Enthusiastic mentoring, autonomy support and the opportunity to present their research more widely all helped the teachers in this Turkish context develop.
\end{abstract}

Key words: teachers' self-efficacy beliefs, research efficacy beliefs, continuing professional development, practical knowledge, teacher research, mentoring

\section{Introduction}

Although the notion of language teachers engaging in practically-oriented classroom research has not always been seen in an entirely positive light, e.g. by Jarvis (2001), who asserts that "whether action research really does (or even can) consistently lead to better teaching practices remains an open empirical question that has not yet been resolved" (p. 1), the situation is changing (e.g. Borg, 2003; Smith, 2015). Teacher research, which can be 
defined as "systematic, rigorous enquiry by teachers into their own professional contexts, and which is made public" (Borg, 2009, p. 377), can be regarded as a highly beneficial activity (Wyatt, 2011), improving teachers' "practical skills, deepening their knowledge of both the theoretical and practical aspects of language teaching and learning, motivating them to continue their professional development efforts on their own in the future" (Çelik and Dikilitaş, 2015, p. 15), promoting collegial collaboration (Atay, 2008) and encouraging greater autonomy amongst more efficacious teachers (Henson, 2001). In this article, our central focus is on how changes in teachers' self-efficacy beliefs and practical knowledge can be stimulated by research engagement and the development of more positive efficacy beliefs in conducting research. These are relationships we explore in relation to the longitudinal development of three in-service teachers of English working on a foundation programme at a university in Turkey. Before describing the qualitative case study research methodology employed and presenting our results, we first review the literature.

\section{Literature review}

In the last two decades, understandings of teachers' self-efficacy beliefs, which are centred on their beliefs about their abilities to fulfil context-specific tasks that support valued learning outcomes (Wheatley, 2005), have gradually become more refined (Chesnut and Burley, 2015). Consequently, there has been greater research focus recently on teachers' specific behaviours, e.g. use of students' cultural background to help make learning more meaningful (Siwatu, 2007, 2011) or use of group work to support low achievers (Wyatt, 2010).

Accompanying this greater interest in context- and task-specific teachers' selfefficacy beliefs has been growing awareness, as in Cabaroglu (2014), Henson (2001), Wyatt $(2013,2015 a)$, that such beliefs are relatively fluid and indeed open to being impacted positively by continuing professional development (CPD) of a 'transformative' nature (Borg, 2015). Such understandings, i.e. that in teachers' self-efficacy beliefs there is potential for growth, are still by no means universal, though, partly because many researchers still confuse taskspecific beliefs with the more global beliefs that dominated much of the early (pre- Bandura, 1997) literature. Chacón (2005), for example, describes teachers' self-efficacy beliefs (portrayed in her study in global terms) as likely to be formed early, self-perpetuating and fixed, while Tschannen-Moran and Woolfolk Hoy (2007, p. 947) argue that these beliefs are "most pliable" early on in a career. 'Pliable' is an interesting choice of adjective in itself, collocating less readily, in the British National Corpus, for example, with the notion of individuals being actively engaged in their own development with the capacity to drive change themselves, a concept which is central to Bandura's (1986) theory, and more readily with the notion of minds being manipulated. Interestingly, though, their pessimistic view of the likely non-development of teachers' self-efficacy beliefs (presumably becoming less 'pliable' and more 
'set' over time) is matched by Tschannen-Moran and Woolfolk Hoy's (2007) pessimism regarding professional development opportunities. Experienced teachers, in their view, adapt "to the typical isolation of their work lives", largely ignored save for "the perfunctory twice-a-year visit from administrators with a preprinted evaluation form" (p. 954). For these researchers, teachers' self-efficacy beliefs, once formed, remain fairly fixed in the unsupportive contexts they consider to be the norm.

There are thus two very different positions, which can only really be reconciled by first considering the distinction between teachers' task-specific self-efficacy (TSE) beliefs and their more global self-efficacy (GSE) beliefs more closely. For, though highlighted by Henson, Bennett, Sienty and Chambers (2000) and discussed by several researchers since (e.g. Wheatley, 2002, 2005; Wyatt, 2014a, 2015a), this is a distinction that has been little understood. A TSE belief is focused on a clear agent-means belief (Skinner, 1996), e.g. 'I can use appropriate strategies in this context to correct my second language learners' linguistic mistakes', which is linked to a related outcome expectation (a means-ends belief), e.g. 'being introduced to appropriate strategies in this way will help these second language learners to correct their own linguistic mistakes more autonomously in the future'. As TSE beliefs change, teachers will generalize their efficacy to other tasks and other contexts (Bandura, 1986; Wyatt, 2008, 2015b), in the process forming GSE beliefs, which, since being less context-specific, are likely to become more stable and central within the individual's beliefs system (Pajares, 1992). TSE beliefs, though, following the analysis of different types of beliefs provided by Pajares, are likely to remain relatively fluid. Indeed, as Tschannen-Moran, Woolfolk Hoy and Hoy (1998, p. 227-228) have acknowledged, "teachers feel efficacious for teaching particular subjects to certain students in specific settings, and they can be expected to feel more or less efficacious under different circumstances... even from one class period to another".

It follows, then, that TSE beliefs are likely to be open to impact through 'transformative' CPD (Borg, 2015), particularly if teachers are helped to focus on particular tasks of greatest relevance to their daily lives. When engaging with these tasks, they may of course experience the doubt that is central to reflective learning (Wheatley, 2002), without this necessarily negatively impacting their TSE beliefs in the various unrelated tasks they engage in or their GSE beliefs to any great extent concurrently. Indeed, such efficacy doubts can very beneficially stimulate growth (Wheatley, 2002, 2005; Wyatt, 2010, 2013, 2015a), leading in a spiralling way through reflective cycles, including planning and re-conceptualizing stages (as in Ur, 1996, p. 7), to more confident task engagement (Wyatt, 2008, 2015b).

Experiences of various kinds will impact these developing TSE beliefs, including practical classroom experiences of carrying out the tasks themselves, which Bandura (1986) terms 'mastery' experiences. There are also 
the 'vicarious' experiences that can be gained from watching or hearing about others performing similar tasks, as well as the interactive experiences Bandura terms 'persuasive' that might involve some form of coaching or mentoring. Efficacy-building experiences, according to Bandura, also include 'affective' or 'physiological' arousal, including sudden fear or trepidation.

In practice, these forms of experience might interact in various ways. This can be seen clearly from an account of engaging in action research provided by a pre-service teacher in Cabaroglu (2014) who had been concerned about misbehaving students and had focused on ways of addressing this issue:

At the beginning of the term, I was not good at coping with student misbehaviours (and I thought that they are like this and there is nothing I can do to change it). From the observations, I learned that I should hold a mirror to myself. Before, I was just holding the mirror to misbehaving students (I mean I was blaming them). After I read some articles (and your [the course tutor/mentor's] comments about preventive and proactive strategies), it struck me that perhaps they misbehaved because of some of the mistakes I made in my teaching. Then, I reflected on my own teaching style. I tried to address different learner types like visual, kinaesthetic or aural. I tried to use my body language effectively. I noticed that I should give non-oral feedback. .... In addition to adding colour to my lessons and giving feedback, I tried to make my students feel that I am quite enthusiastic and motivated to teach them (p. 85).

From the above account, we can see the following:

a) The teacher felt inefficacious at the outset ("not good at coping"), and may have engaged in avoidance behaviour (Bandura, 1986); since she felt there was nothing she could do, she may, in some ways, have stopped trying.

b) Feedback on classroom observations conducted by her course tutor/mentor induced reflection on her practices and 'efficacy doubts' (Wheatley, 2002); she realized there might be a problem with the teaching strategies she did employ.

c) Interaction with the literature and comments from the course tutor/mentor encouraged a re-conceptualization of the problem, with her now perceiving herself more as a change agent proactively engaged in her own professional development (Bandura, 1986), and so with the potential to become more efficacious; indeed she seems to have had a 'growth' rather than a 'fixed' mindset (Dweck, 2000), since she felt she could improve.

d) Evidently feeling sufficiently efficacious to tackle the problem, for TSE beliefs influence the way that knowledge is transformed into action (Bandura, 1986), the teacher started planning lessons in a different way, trying innovative strategies to address the issue that was troubling her (and presumably reflecting on these). As a consequence, 
her 'practical knowledge', i.e. the "knowledge most directly related to action ... readily accessible and applicable to coping with real-life situations", and largely drawn from classroom experience (Calderhead, 1988, p. 54), would have grown.

This all helped the teacher "cope" (Cabaroglu, 2014, p. 85); she developed more positive TSE beliefs in managing student behaviour, together with practical knowledge in this aspect of her teaching, and the action research accordingly seemed valuable. The quantitative data in Cabaroglu's mixed methods study of 60 pre-service teachers suggest their GSE beliefs grew through the course, with the practical experience of teaching itself, selfevaluation and developing action plans considered the most useful components of the course, together with feedback on their teaching from the course tutor/mentor.

Similarly positive results have been found in other studies that have explored the impact of engaging teachers in action research to support their own professional development. These include Henson's (2001) mixed methods study of eleven teachers in a school for children with behavioural difficulties who, supported by mentoring, engaged in collaborative action research over an academic year. One teacher, for example, reported: "your growth comes from understanding the real problems you are dealing with" (p. 828). Focusing on the overall goal of developing more productive citizens, these teachers developed specific interventions, such as rewards for good behaviour and peer tutoring systems, put these into practice, monitored and evaluated. Reporting modest successes against their objectives, which thus provided positive mastery experiences (Bandura, 1986) in a challenging environment, all reported efficacy gains and affirmed it had been worth the effort; 10 of the 11 wanted to continue the project the following year (Henson, 2001).

Other longitudinal studies include Wyatt's (2008) multi-case study of five inservice English language teachers in Oman. Focusing on teachers who had chosen action research designs for 15-month projects that were part of an award-bearing CPD course, this reported TSE beliefs gains with regard to particular tasks (e.g. using group work to support low achievers), and efficacy gains with regard to reflective actions (e.g. analysing and adapting course materials, monitoring learning and evaluating learning outcomes); psychological changes appeared to be reflected in changes in practical knowledge and observed teaching behaviour. However, while this study (based on observations, interviews and analysis of reflective writing) and those developed from it provided evidence of teachers overcoming low TSE beliefs (Wyatt, 2013), and synergy between developing TSE beliefs and practical knowledge (Wyatt, 2010), it also uncovered evidence of teachers who seemed over- and possibly under-efficacious (Wyatt, 2015a), this 
demonstrating the need for a combination of qualitative research methods, including observations, to question declared TSE beliefs.

One dimension to TSE beliefs growth not explored systematically by any of these studies, notwithstanding their focus on reflective actions, is the relationship between these beliefs and developing efficacy in different aspects of being a teacher-researcher. Borg (2010) suggests, for example, that teacher research should be purposeful, methodologically appropriate, technically competent, ethical, critical, coherent, and able to make a contribution. These criteria suggest dimensions of 'teacher research efficacy' (TRE) beliefs, such as the following: To what extent are teachers efficacious in identifying issues that need researching, in developing specific research questions and focused literature reviews, in choosing suitable research methods and justifying these, in designing appropriate research instruments and using these for data collection and analysis in deeply ethical ways, in being critical while producing research that contributes to knowledge, in producing coherent research reports in both oral and written form? It is, of course, quite likely that efficacy growth in these areas might be uneven since becoming a teacherresearcher clearly involves developing knowledge in different areas and of different types, and complex skills, over a period of time. However, to the best of our knowledge, the notion of TRE beliefs remains as yet unexplored as a separate construct in the literature.

There is a growing body of teacher cognition research, though, that has explored language teachers' conceptions of research (e.g. Borg, 2013), and this suggests that these are often under-developed. Summarizing findings of a survey of 505 teachers of English in 13 countries, for example, Borg (2009) highlights that most teachers surveyed held notions of research aligned with 'objective', large-scale hypothesis-testing in the 'positivist' tradition (Cohen, Manion and Morrison, 2007), although paradoxically perhaps many also affirmed that research should "give teachers ideas they can use" (Borg, 2009, p. 368), an aim that can also be served by other research paradigms, including the 'interpretive' and the 'critical' (Cohen, Manion and Morrison, 2007), the latter realized, for example, through approaches such as 'collaborative action research' (Burns, 1999) and 'exploratory practice' (Allwright and Hanks, 2009). An unfortunate consequence of teachers having "inappropriate or unrealistic notions of the kind of inquiry teacher research involves" is that then research is confined to being "a minority activity" in English language teaching (Borg, 2009, p. 377). However, other factors, as Borg explains, including attitudinal and environmental, e.g. relating to workload, also impact this. In Chile, for example, as Smith, Connolly and Rebolledo (2014) report, teachers tend to spend about 38 hours per week instructing large classes containing approximately 40 students, so time for teacher research is limited. Furthermore, in this Chilean context, as these authors continue, the CPD provided has tended to be top-down in nature, with changes imposed from above insufficiently context-sensitive. Meanwhile, encouragement for 
teacher research from educational administrators at both local and national level has been sadly lacking or almost forbiddingly academic in tone.

If most teachers do not engage in research, as Borg (2009) indicates is likely to be the case in many parts of the world, because of such difficulties, this suggests low TRE beliefs. While such beliefs are presumably overcome amongst the teachers who become researchers, while developing through their careers from 'novices' with very limited experience towards expertise (Berliner, 1988), this growth process in itself (of becoming a practicallyoriented classroom researcher) has not as yet received much attention (Borg, 2013). Where 'transformative' CPD (Borg, 2015) is provided, though, it is thought that the following help the developmental process:

- awareness-raising

- opportunities to gain practical knowledge by conducting small-scale classroom research

- the encouragement of reflective skills

- mentoring

- more formal input through workshops

- a supportive school environment

- opportunities provided teachers to present and publish their research (Dikilitaş, 2015; Wyatt, 2014b)

Since such help was available for the teachers in our study, we will consider how these various factors impacted developing efficacy beliefs and practical knowledge. This is while exploring the longitudinal development of three teacher-researchers in a Turkish context that is first described below.

\section{Research context}

As noted above, the research took place with teachers of English on a Turkish university foundation programme. The university, founded in 2009, is situated in a city on the west coast of Turkey. It offers Bachelor and Masters degree courses in architecture, engineering, health, law and management, mostly using English as the medium of instruction.

One of the authors (henceforth, the 'teacher trainer') was recruited in 2010 to support the then 40-45 (now 60-70) teachers who work on the English language foundation programme. These teachers (many of whom are novices with less than three years experience) spend approximately 24-28 hours per week in the classroom in 4 eight-week blocks between September and June each year, taking approximately 700-800 learners through to the end of the Common European Framework B2 (upper-intermediate) language proficiency level, so that they are then able to cope with academic studies in their core degree subjects. The English curriculum follows a main course book, together with skills books for reading, writing, listening and speaking. 
Faced with the challenge of supporting these teachers, the teacher trainer decided when he took up the post in 2010 to promote engagement with research as the main CPD activity at the university (although within the professional development unit he would run he would also support teachers in other ways, e.g. through conducting classroom observations for developmental purposes). As he reported in interview to Richard Smith in 2012, this impetus to support research engagement

came from his own overall learning experience, and from a resulting belief that people should discover relevant knowledge for themselves rather than expect to be 'fed' with it... He had heard of action research and was attracted to it as it seemed consistent with this underlying philosophy (Smith, 2014, p. 16).

This philosophy, which can be seen in terms of supporting 'experiential learning' (Kolb, 1984) through socio-constructivist 'scaffolding' (Vygotsky, 1978), was shared by colleagues from other universities who the teacher trainer interacted with (Çelik and Dikilitaş, 2015), and this supported the initial planning. Once in post, the teacher trainer put his ideas into practice immediately, explaining, in his first sessions with the teachers, "his beliefs about teacher-learning, saying he would not be prescribing to them how to teach" but instead wanted them to engage more autonomously in their own professional development (Smith, 2014, p. 16). However, there was some resistance, as the teachers were more familiar with a top-down 'trainingtransmission model' of CPD (Borg, 2015). Indeed, "some reacted negatively, questioning [the teacher trainer's] way of proceeding and referring to the way their friends teaching on programmes elsewhere were being trained" (Smith, 2014, p. 16).

Nevertheless, the teacher trainer persevered. He introduced them to teacher research in CPD sessions in a systematic way (Dikilitaş, 2014), "stressing the value of collecting data to gain insights into [their] own classroom, and giving examples from books by Anne Burns and Michael Wallace" (Smith, 2014, p. 16). In weekly meetings, he tried to develop more positive feelings about research and then provided research skills training, including that in data collection and analysis, which was much needed. Indeed, "as the teachers had little to no experience in carrying out research of any kind, many of them were anxious about this aspect of the project, which led to problems with selfconfidence" (Çelik and Dikilitaş, 2015, p. 7).

As well as holding these weekly meetings, the teacher trainer encouraged the teachers to reflect on problematic areas in their teaching, and meet him oneto-one to discuss these. He would help them find relevant articles on the topic and then, when they were ready, give a mini-presentation at the weekly meeting (Smith, 2014). Research projects gradually developed, and, at the end of the academic year, a two-day conference was held, when 24 of the teachers presented their research (through a total of 20 studies since some were 
collaborative). The teacher trainer encouraged these teachers to write up their presentations, which were collected and published (Dikilitaş, 2012), establishing a pattern that has been followed in each successive year (Dikilitaş, 2013, 2014); the following year, for example, 28 teachers produced 24 studies between them (Dikilitaş, 2014). Furthermore, since its inception the annual conference has become more international, supported in particular by Richard Smith and the IATEFL (International Association of Teachers of English as a Foreign Language) Research Special Interest Group. Plenary speakers have included Dick Allwright, Simon Borg, Anne Burns and Martin Lamb.

In this context, then, there are various indicators that, despite various constraints including heavy workloads, there has been considerable sustained engagement in teacher research (Dikilitaş, 2014), with support that has focused on developing positive attitudes towards research, developing research skills and critical thinking, and heightening teachers' awareness of their learners (Çelik and Dikilitaş, 2015; Dikilitaş, 2015; Smith, 2014). This seems to be the kind of environment, then, in which growth in TSE beliefs (in the ways described above) and practical knowledge may occur. Indeed, the impetus for the research reported on here came from the teacher trainer's reflection (shared with the other author, the first researcher) that such growth seemed to have occurred in teachers he had worked with closely over several years while helping them become researchers.

\section{Research methodology}

To develop an understanding of how teacher-researchers in this Turkish context had developed over time, perhaps becoming more efficacious as researchers while also developing more positive TSE beliefs with regard to specific aspects of their work and, at the same time, growing in practical knowledge as teachers, which we felt might have been the case, we decided to adopt a qualitative, multi-case study approach (Stake, 2006), focusing on a small sample of teacher-researchers we could explore in-depth. This is essentially a 'developmental study' (Cohen, Manion and Morrison, 2007, p. 205), concerned with describing the "present relationships... among variables in a given situation and [accounting] for changes occurring in those relationships over time". Through adopting this approach with a small sample of individuals and producing 'thick description' (Geertz, 1973), we aim to shed light on "the unique vitality of each case" (Stake, 2006, p. 39), while also drawing comparisons between cases to inform theory.

The strategy we adopted was to first provide some general information about the research and call for volunteers from amongst the teacher-researchers currently working on the foundation programme at the university. 14 volunteered, providing informed consent, and completing a TRE beliefs survey (discussed below); they were guaranteed confidentiality and anonymity. However, the three selected subsequently by the teacher trainer, 
on the basis of criteria such as balance, variety and what it was felt could be learned from them (Stake, 1995), waived anonymity. This should enable the reader to cross-reference our accounts of their development against their own reports of the classroom-based research they have conducted; these have been published in several successive edited collections (Dikilitaş, 2012, 2013, 2014; Dikilitaş, Smith and Trotman, 2015).

This is 'insider research' co-authored by the teacher trainer who was intimately involved in the teachers' development. Given this consideration, reflexivity was clearly required constantly at every stage of the research to understand the possible effects of the teacher trainer/researcher on the setting and also to explore how this presence could be capitalized on (Holliday, 2002).

The first objective was to gain insights into the teachers' TRE beliefs and how they felt these had changed over time and why. A survey was developed, based on Borg's (2010) analysis of criteria for good quality research (Appendix 1); this was completed by the teachers and emailed directly by them to the first researcher, who had spoken at their annual conference in the previous year and thus had some familiarity with the context, without however knowing the 14 teachers very well.

The first researcher informed the teacher trainer which teachers had volunteered (and summarized the data, some of which will be used in a subsequent study). On the basis of his prior knowledge of the teachers and the criteria discussed above, the teacher trainer then selected three for the multi-case study. Using his field notes as well as accounts provided by the teachers of their research, he then developed first-draft narratives of the teachers' development and 'member-checked' these with each teacher, a procedure recommended by Stake (1995). He then sent these drafts to the first researcher, and an email discussion ensued, when clarifications were sought and interpretations questioned. The first researcher scrutinized the documents the teacher trainer had used (including the teachers' written reflections) and developed the drafts further, also adding in data from the TRE beliefs surveys. The teacher trainer added to these drafts and then member-checked them again with the teachers. It was at this point when the teachers were asked whether they would prefer their real names used or pseudonyms. They chose the former, confirming the narrative accounts as accurate representations of their stories and indicating they were comfortable with being identified. We now present these narratives and discuss them in relation to the literature.

\section{Findings}

Rukiye

When Rukiye first engaged in teacher research, in 2010 at the commencement of the project, she was already an experienced language learner and teacher, 
having studied English Literature in Germany and Turkey, and having taught English as a foreign language to young learners and adults. She believed deeply, she reports, in the value of CPD and committed herself to the research project immediately, focusing in her first study on supporting the development of her students' writing skills through getting them to work together in groups. Conducting this action research, which involved engaging 60 learners in four classes in collaborative writing tasks, observing their behaviour, analysing the results and eliciting their views of the process, strengthened her beliefs in the value of collaborative learning. Indeed, she argued: "For the sake of a socially open and academically sharing classroom, in which students are all involved in studying eagerly, we should try collaborative learning activities." Nevertheless, despite her successes with this approach, Rukiye reported later that while she completed, presented and wrote up the research study, it took her some time to understand teacher research; it was still something of a mystery then.

Rukiye subsequently attributed this initial uncertainty to coming from a Literature background and never having conducted classroom research before. She had not yet internalized research processes, she reports, and was focused far more on the teaching than on the research. Our data triangulate this, as it is evident from examining her first study that the account of the teaching process was far more fully developed than that of the research methodology she had employed. For example, she said very little in this study about the process of interviewing her own students, apart from telling us she did so and listing the questions asked.

Another feature of this first study is that the literature review was very welldeveloped. Indeed, Rukiye reports that even now exploring the literature in relation to the topic is something she feels particularly efficacious about:

Doing the literature review is actually the part that I like most. Therefore, I find myself capable of this since I really make a lot of efforts when it comes to the literature review. I'm also really curious about other people's researches and I mostly benefit from them.

Evidence of Rukiye benefiting from the literature is clear in her second study. Indeed, she emphasized in this that it had helped her distinguish between 'errors' and 'mistakes', the former relating to developing linguistic competence, the latter simply to performance (Corder, 1987).

Before this study, I used to overcorrect students' written products. Besides, I used to interrupt them a lot while speaking English. I couldn't help but intervene all the time. However I learned that I hadn't known the difference between error and mistake. The fact that students made mistakes was a sign of "not learning" to me.

This second study was primarily exploratory, with Rukiye focused on discovering how different pedagogical techniques such as underlining text or 
indicating the number of items to detect in a sentence helped learners correct the 'surface' mistakes they made that might be a product of carelessness. This was with a view to supporting them to correct their own mistakes more autonomously in the future. Rukiye reported that this helped her gain a greater understanding of learning processes.

Focusing more on learners' feelings, Rukiye returned to the same theme (correction) in a subsequent study, contextualizing it so:

I don't know how many times I have felt anxious whether or not to correct a student who made a mistake in class. The dilemmas of letting mistakes happen or discouraging students has always confused and bothered me. On one hand, I did not want to spoil students' motivation; on the other hand, I did not want to ignore the incorrect use of the language.

This suggests she experienced 'teacher efficacy doubts' (Wheatley, 2002), which beneficially encouraged Rukiye to engage in action-oriented research. She focused in this new study on exploring students' preferences for different pedagogical methods (e.g. recast, clarification request, metalinguistic feedback, elicitation, explicit correction and repetition [Brown, 2000]) that can be used to give students feedback on their linguistic mistakes. Rukiye consciously used each of these methods in turn over six weeks, while not neglecting the others, and elicited the learners' reactions.

While there were numerous challenges, with Rukiye reporting, for example, that at the beginning "the students had no idea of correction methods", she persevered (perhaps encouraged by previous successes) and subsequently felt rewarded:

During the six weeks in which I used the six feedback methods, I was not sure if I was walking on the right track. Whenever I asked the students to reflect on our practice, I had a slight fear of not being able to get their honest opinions. However, I realized that I had been wrong. My students' reflections were not only honest but also very helpful. Moreover, they told me that they had been really pleased when I asked them to share their opinions with me.

The 'slight fear' Rukiye reports experiencing here before eliciting student reactions, which can be seen in terms of 'physiological arousal' (Bandura, 1986), would have beneficially encouraged her to question her (innovative) practices, as 'efficacy doubts' (Wheatley, 2002) can do. Crucially, she believed she was conducting the research ethically, something she has since reported feeling efficacious about: "I think I'm very attentive when it comes to [this]. Everything related to action research depends on voluntariness, mutual trust (participants and researcher) and the truth". 
Rukiye appears to have benefited from the social interaction that has been part of her concrete experience (Bandura, 1986) of doing research. This seems to have increased her efficacy beliefs for engaging learners to participate, as she reports: "The fact that students mostly enjoyed participating in these researches made me feel satisfied and more enthusiastic". She stresses too that she has benefited from social interaction in other ways, emphasizing that vicarious experience from regular meetings with colleagues and mentoring from the teacher trainer have helped her throughout her research journey. As a result, she says: "Our collaborative skills are enhanced". Presenting her research in front of an audience is also something she now feels "more comfortable with". Indeed, she reports: "The audience's enthusiasm keeps me enthusiastic as well."

She is conscious of the personal benefits, declaring: "I have become more critical and open to inquiry". She reports being more flexible, "always open to changing and updating" herself, so that gaining insights, e.g. into the content of her learners' feelings with regards correction, "can always be helpful" to her as a teacher.

As a consequence of all this, she reports "as time passes I get better at doing research", which is clearly the stance of an efficacious teacher. Rukiye believes that conducting research has been integral to her growth, highlighting that she feels more self-confident since the outcomes of her research have helped her in her classes.

\section{Nur}

Nur, who like Rukiye is a teacher with an English Literature background, also joined the research project in 2010. This was after two years' initial teaching experience, the first year at a private language school and the second at the university; so she was still a comparatively 'novice' teacher at this time.

Nur initially struggled to engage in classroom research. She explained she really wanted to focus on her students' comprehension problems, both in listening and reading, but "needed to understand more about how to conduct [classroom] research" before she could engage in this. Indeed, reflecting recently, she has reported that when it came to tasks such as designing research instruments she "had no idea" that could guide her at this stage in her development. Moreover, study commitments (she was working towards a part-time MA in English Literature) also considerably reduced the time available for collecting and analysing data. Consequently, while many of her colleagues, like Rukiye, engaged in their first practical research activities, which they subsequently presented at the local conference and wrote up, Nur restricted herself to a more theoretical contribution, focusing on the implications of schema theory (Carrell and Eisterhold, 1988) for the development of reading and listening skills. In the paper she produced, Nur listed activities which, she argued, could support "a more interesting and 
productive class atmosphere, leading to a more efficient lesson", but her ideas were based on the literature rather than practical classroom research, for which, she acknowledged, she was still inefficacious.

Nur became more self-confident about conducting practical classroom research in the next two years, through engaging collaboratively with colleagues while supported by mentoring. The first of her research projects involved investigating low level students' pragmatic knowledge, particularly their classroom requests. She had noticed these were often inappropriate, e.g. "teacher telephone" (to ask for permission to go out during the class to make a phone call) or "I go to toilet". With a colleague interested in the same issues, Nur investigated the strategies her learners used, observing them and making notes over a three-month period and then asking them to participate in discourse completion and multiple choice tasks. After analysing the results, important actions to take into the classroom she identified were the need for the teacher to become a role model in the use of appropriate language, and the need for learner strategy training. Nur felt she benefited considerably from this inquiry as it gave her practical knowledge in addressing classroombased pedagogical concerns "by means of problem-solving techniques and new approaches" centred on action research. Working with a colleague had been very useful, she reported, as they had shared ideas, analysing the data together. "I developed self-confidence in doing research to some extent", she reflected later, "which wasn't the case in the first year".

Nur's next collaborative research, conducted at a time when she was still busy with her MA commitments, was with four colleagues, who focused together on understanding how student motivation could be improved. First, they engaged the learners in class discussions, probing about issues of low motivation indirectly, e.g. by pointing out that some learners did not seem to participate much in classroom activities and eliciting possible reasons for this. The teachers then observed each other, developed lesson plans collaboratively and then taught them to their classes while observed by the other group members. They also gave the students a questionnaire, and insights were gained from this research into how various factors impacted student motivation. Nur reported benefiting from her research engagement in this project in various ways. In particular, she noted: "I developed more selfconfidence in working with this group, especially in the discussions about the observed lessons." So, in this respect, the collaborative nature of the process was beneficial in helping her develop more positive self-efficacy beliefs in conducting research. However, there were also some frustrations, as the group of five was perhaps too large for this kind of study. She reported: "It was hard to orchestrate the process, especially when we needed to come together and discuss issues emerging, as we had different workloads and timetables." As a consequence, she felt the depth of involvement was sometimes superficial, and she lamented: "there was not enough dynamism to push me forward and to give me motivation to understand more about my 
own motivational strategies". While, therefore, Nur felt only partially satisfied with the outcomes of this research project, she nevertheless seemed ready to take greater control over her own professional growth by developing her own research plans more autonomously.

Nur's next research project was an individual one focused on an aspect of her teaching she had been aware of for some time, namely lengthy teacher talking time (TTT) in the classroom; excessive TTT can be seen as problematic in language learning contexts if, for example, it reduces the time available for students to communicate in the target language (Thornbury and Watkins, 2007). In this Turkish context, Nur's quite lengthy TTT had been the focus of post-lesson discussions carried out by the teacher trainer, following observations he had conducted for developmental purposes. Now Nur decided to investigate her own classroom talk to address this long-standing issue. First, she recorded one of her lessons and transcribed the teacher talk, then categorizing the functions of this, e.g. asking questions and repeating them, repeating students' responses, repeating her instructions when not understood. From this analysis, she gained insights into her practices, reporting she had "determined [her] weaknesses in terms of teacher talk and reflected on these". For example, she wrote: "I dominate the class... students do not have the opportunity to generate questions to ask each other... there is no need to echo the students' answers; students can repeat their answers if not understood".

Nur developed and then employed strategies to reduce her teacher talk, such as encouraging peer checking; she then recorded another lesson two weeks later. Analysing this, she noted progress, e.g. in increased student talk, with her learners more involved in asking questions of each other and of the teacher; there was less error correction from the teacher, less reading aloud from the course material and less echoing, although, partly perhaps because of the number of coursebook exercises in this lesson, the quantity of teacher talk for instructions actually increased. This prompted Nur to develop further strategies, such as using visual symbols with meanings such as 'work as a group' to encourage the students to follow instructions. To some extent this succeeded. A third lesson recorded two weeks later revealed clear progress in Nur's bid to reduce her TTT, although she highlighted further strategies she could employ, such as continuing to increase the amount of pair and group work, which had already had a beneficial impact, perhaps by modifying course materials. Reflecting on this experience of action research, Nur is conscious not only of how it has benefited her learners but of how engaging in this project has aided her development too. She reports:

I got the opportunity to act in various teacher roles which I did not use before, [helping] students learn and speak while I was actually not very active as a teacher, more of an observer and resource instead. And I learned the significance of being more open-minded and able to reflect on my practices in class. 
She reports feeling more efficacious with regard to providing opportunities for student talk in her classes, and more efficacious with regard to doing research independently to further her own professional development. "I have developed critical thinking ability and confidence to explore the underlying reasons of the problematic areas", she reports: "from now on, I can observe myself more realistically and critically". Clearly, her practical knowledge has grown. She highlights the supportive role of the teacher trainer scaffolding her towards independence and the value of in-house training that has helped her understand problems from different perspectives. Summarizing the benefits of research engagement, she reports:

Doing research definitely helped me while I plan my lessons and design my materials. It gave me the insight to look deeper for the reasons of some problems in teaching and learning English. It gave me the confidence to question my and others' practices in teaching. Doing research studies every year at the university has helped me learn my job better and more efficiently.

\section{Koray}

Prior to joining the university in 2012, Koray, a young teacher with a British educational background, had gained two years' teaching experience in private language education in Turkey, working with young learners and adults. After this, deciding to make teaching his career, he took a CELTA (Certificate in English Language Teaching to Adults) course locally, which qualified him to work at the university; this immediately brought him into contact with the notion of teacher research for professional development, since this was expected of the teachers.

Koray reports, however, that initially he was unsure what teacher research was and, as a result, was rather sceptical about possible benefits, reflecting: "how good can this be if we don't have the skills to do it properly?" Despite his reservations though, he developed a research project cooperatively with a more experienced colleague; they focused their study on teaching phrasal verbs, which were a problematic part of the syllabus (since learners struggled with them). They sought to discover what learners thought about the value of different teaching methods used with phrasal verbs (assessed through interview) and how these methods supported the retention of vocabulary (assessed through tests).

In some ways, this initial experience gave Koray confidence in practically conducting research; he reported feeling more efficacious than he had at the start in collecting and analysing data, and writing up the results. Nevertheless, when he reflected further on the study he also felt dissatisfied; the activities conducted in class with the learners "were very mechanical; the students weren't given the knowledge... [or] the opportunity to explore where and when to use [the phrasal verbs]". He felt that he and his colleague 
"could have asked students about the difficulties they may have previously encountered when learning phrasal verbs, and tailored [their] methods according to the specific needs of [their] learners."

Koray sensed then that learners could gain more from teacher research that was more closely focused on their needs. This was an understanding that he reports developing through the next year as, after volunteering to help out in the professional development (PD) unit, he came into contact with many teacher-researchers, both at his university and elsewhere. Taking on this extra PD work, to which he brought valued qualities such as a concern for learnercentred pedagogy, well-developed skills in analysing language and enthusiasm, was out of eagerness, he reports, to develop further as a researcher. There he had constructive discussions on a wide range of professional topics with the teacher trainer, conducted classroom observations to support teachers' needs analysis, and helped design workshops with his colleagues. Koray affirms that he really appreciated having this opportunity as it helped him to clarify his understandings, so impacting his practical knowledge. His next experience of designing action research was shaped by this exposure to others' research ideas and his own reflections during this time.

Koray's second intervention was focused on adjusting grammar instruction to meet learners' needs, an impetus triggered by a realization that some learners may have preferred a more explicit approach to grammar teaching than the implicit approach he favoured; his approach, he realized later, had been based on his own prior learning experiences in the UK and his CELTA training, but may not necessarily have reflected his learners' expectations in this university context. Indeed, in this context, Koray had noticed that students' notebooks were full of grammatical forms and substitution tables. So Koray paired up with a colleague who reported favouring a more explicit teaching of grammar and they observed each other's classes three times, met regularly together and consulted the teacher trainer, who had helped them refine the focus of their research. They experimented with different approaches, both 'inductive' and 'deductive' (Scrivener, 1994), videoed these lessons and played their recordings to focus groups drawn from their classes; they asked the students to comment on their preferences regarding approaches to grammar teaching.

The study generated insights that shaped the teachers' practices. Koray reports that it helped increase his awareness "of students' expectations and needs as second language learners" with regard to grammar teaching, and that from now on he would be more flexible in his approach. So he now thought he should follow both inductive and deductive approaches to grammar teaching as a result of his developing awareness of the Turkish students' preferences. He was also aware of having developed his knowledge as a researcher, in particular of "the different models of peer observation, with their differing advantages and disadvantages for reflective practice and 
teacher development". Indeed, he affirms that beforehand he had no idea how valuable engaging in the peer observation research would actually be, nor "how difficult".

In practice, the teacher trainer had provided considerable support to reduce the challenges, Koray acknowledges, helping them "deepen the study and narrow [their] attention on the main issues". "He was there", Koray reports, to provide useful feedback at every stage in the process, from when they were developing research questions, through to analysing data and finally writing up. However, Koray had also benefited, he says, from "continuous support from peers and critical friends". These supportive interactive experiences had really helped.

As well as deepening his understanding of the value of conducting such learner-sensitive investigations, Koray highlights that, together with his practical knowledge, his self-efficacy beliefs as a teacher researcher have increased. He now feels "more confident in [his] teaching practice", more conscious of how to explore learners' needs and better able to take action. And he affirms that students in grammar classes besides those he did the research with "have also benefited from personal reflections" stimulated by his research.

\section{Discussion}

We now discuss these cases together and in relation to the literature for what they can tell us about how the development of teachers' self-efficacy beliefs can be supported through engaging them in action research.

One point of similarity is that all three teachers were new to classroom research prior to joining the project and their initial engagement was limited by lack of practical knowledge of research and apparently low TRE beliefs, particularly in designing research instruments and collecting data, in the cases of Rukiye and Nur. Different types of beliefs do interact, though, in complex ways (Pajares, 1992), and, in Rukiye's case, beliefs in the value of CPD seem to have stimulated her to engage in research, over-riding her uncertainty as to how to proceed with this. In Nur's case, though, inefficaciousness in conducting classroom research resulted in avoidance behaviour, as Bandura (1986) suggests might happen. Such inefficaciousness might also result in a downplaying of the value of the behaviour expected (Wheatley, 2002), and indeed, in Koray's initial reaction, the benefits of doing classroom research were questioned.

Subsequently, though, all three teachers engaged wholeheartedly in research, efficaciously involving their learners fully in the process. Indeed, in the teachers' developing understandings of research in relation to their specific tasks, making the learners' feelings central to the process seems to have become more important to them over time. Thus, Koray felt dissatisfied with 
his first research project in retrospect, recognizing that the teaching methods researched may have been insufficiently focused on the learners' specific needs, while his second research project led him to question prior assumptions about grammar learning and teaching, and build greater flexibility into his pedagogical practices. Similarly, Rukiye, while also learnercentred as a teacher throughout, moved from researching the 'collaborative learning' practices she assumed would help her students most to investigating their feelings (about her pedagogical techniques). Such developments seem to demonstrate a greater awareness of the 'exploratory practice' principles underpinning classroom research (Allwright and Hanks, 2009) the teachers had been exposed to through various sources, e.g. the teacher trainer, workshops, readings and conference speakers. In these 'exploratory practice' principles, concern for the learner is central. Such a heightened awareness of their learners might also be reflective, though, of the teachers' developing experience over time (Berliner, 1988), particularly since this experience was intensified through their engagement in empowering CPD (Borg, 2015).

The teachers were engaging in research as 'knowledge generators' (Borg, 2015), focused on topics of immediate concern in their teaching context that they had identified themselves (Smith, 2014), and were engaging critically, reflectively and collaboratively to address these real world concerns or 'puzzles' (Allwright and Hanks, 2009), involving their learners ethically in this process. Such engagement, "by teachers for teachers" and their learners (Smith, 2015, p. 207), was possible because of the efficacy-building support (Bandura, 1986) provided at every stage. The teacher trainer was the pivotal figure, Koray's words above confirm, providing mentoring from the time when they were focusing on the topic and then advising through the data collection and analysis process to presenting orally at the conference and subsequently writing up. It would have been very difficult to proceed without this mentoring. Other support mechanisms put in place were also valuable, though. Regular meetings with colleagues were highly regarded, as Rukiye confirms, while a key project feature, helping the most 'novice' researchers to engage, was the encouragement to work collaboratively. This is evident in Nur's research trajectory, for engaging collaboratively helped her overcome an initial lack of self-confidence and then sustained her until she had developed sufficiently positive TRE beliefs to conduct research more autonomously on her own. This trajectory in itself demonstrates what an empowering tool CPD can be, when experienced intensely over time, leading to highly positive changes in teachers' self-efficacy beliefs, both global and specific (Cabaroglu, 2014; Henson, 2001; Wyatt, 2008, 2015b).

The cases reported on here provide various insights into the processes whereby changes in such efficacy beliefs (TSE and GSE) can be impacted through CPD. In relation to the specific tasks they set themselves (concerning correction techniques, inductive/deductive grammar teaching, TTT), the 
teachers developed positive TSE beliefs, spurred on, particularly evident in Rukiye's case given the language she uses to describe them, by reflection and 'efficacy doubts' (Wheatley, 2002; Wyatt, 2013). Unsure (and therefore relatively inefficacious) regarding techniques used to correct learners' linguistic mistakes, she focused intensely on her practice and researched the outcomes of this, eliciting the reactions of her students. Such reflective research practices led to more positive TSE beliefs for the reasons she provides: greater criticality, greater flexibility, deeper awareness of and sensitivity towards context-appropriate pedagogical practices. Such growing TSE beliefs tend to be generalized by teachers (Bandura, 1986), so that more positive GSE beliefs, the focus of much of the literature (Wyatt, 2014a), develop.

The cases reported on here also provide insights into how TRE beliefs (as noted above, not previously explored in the literature) might grow. Carrying out 'good quality research' autonomously (Borg, 2010) requires the development of knowledge in different areas and complex skills. Indeed, since becoming a teacher-researcher involves so many different qualities, shaped by a variety of personal factors, including history, it is therefore perhaps not surprising if growth in this appears uneven across different skills and knowledge areas. We see such unevenness, for example, in Rukiye's case, where, given her academic background, personality and prior experiences, developing the literature review was something she initially felt most efficacious about, and is still something that engages her intensely. Rukiye has nevertheless developed more all-round research skills over time, e.g. in collecting data from students while engaging them collaboratively in the process; she has developed practical ways of working that have strengthened her TRE beliefs. An even more pronounced development in this direction can be seen in Nur's case, particularly since Nur initially avoided practical classroom research altogether in favour of the literature review. Subsequently, however, Nur engaged in observing her learners over an extended period, collaboratively analysed the data and planned interventions; she carried out peer observations and engaged in group post-lesson discussions; she turned the spotlight on herself, audio-recording her classroom discourse, transcribing and analysing it. All of these experiences, as she has reported, increased her self-confidence in conducting practical classroom research. Similar developments can be noted, too, in Koray's case, in the way he learned to engage with learners in the data collection process and work with peer observation critically and collaboratively, deepening his understandings of research and becoming more efficacious about conducting research in the process. However, there were benefits besides more positive TRE beliefs. Indeed, these language teachers' cognitions regarding research overall (considering other types of beliefs and knowledge too) seem more fullydeveloped, more finely-nuanced than those of a great many less researchengaged teachers working in different international contexts, e.g. many surveyed in Borg's $(2009,2013)$ studies; this is testimony to the power of 
practitioner-oriented, 'knowledge-generating' CPD (Borg, 2015) in a context where it is so deeply encouraged (Smith, 2014).

\section{Conclusions}

Clearly, considerable personal growth in the areas discussed in this article, including TSE, GSE and TRE beliefs, seems to have occurred in the teachers studied in this context, and CPD as research engagement seems to have been instrumental in supporting this growth. However, we should add a note of caution. We must emphasize, for example, that these teachers' journeys are by no means complete; they are still ongoing and there is still room for them to grow as teacher-researchers. In the cases of the two with very little prior teaching experience (Nur and Koray), perhaps this is just the start. On a related point, we should also acknowledge that not all the development observed in this study is likely to have been due to research engagement as CPD. Over time, these teachers would also have matured anyway (Berliner, 1988), with reflection in and on action (Schön, 1983) instrumental to this.

We should also add a note of caution regarding the research methodology employed. Given that this was essentially a 'developmental study' (Cohen, Manion and Morrison, 2007), it relied, to a certain extent, on memories of the past to relate to the present, and of course memory can be faulty. This threat was countered to some extent, though, through reference to written documents produced by the teachers at earlier stages in their research journeys, including those accounts published in Dikilitaş $(2012,2013,2014$; Dikilitaş, Smith and Trotman, 2015) and therefore open to co-analysis; the teacher trainer, who had been with them on their research journeys throughout, had also kept notes to refer to.

This was, of course, 'insider research' and in examining the teachers' words we considered the possible effects of the 'social desirability response bias' (Collins, Shattell and Thomas 2005), particularly when they discussed the role of the teacher trainer in helping their development. However, as the teachers emailed their TRE beliefs surveys to the first researcher, who was less an insider, this may have reduced 'reactivity' (Holliday, 2002) to some extent. A similar strategy was employed by Smith (2014), who reports eliciting written reflections from foundation programme teachers such as these (from the same population) in 2012, by which time he was a critical friend of the teacher trainer. This was with a view to evaluating the research project, as a relative outsider. Interestingly, in Smith's study, which elicited qualitative comments, the teacher-researchers who responded reported being more self-reliant and self-aware than they had been before the project, and were conscious of students' self-awareness being raised through being engaged in research initiated by their teachers, findings that resonate with the current study.

A key reason why this research project seems to have succeeded to such an extent is the enthusiasm and drive of the teacher trainer, together with the 
scaffolding provided through participant-sensitive mentoring (Smith, 2014) and the opportunity for teachers to present and publish their research (Dikilitaş, 2015). As acknowledged by another researcher in the same geographical context but at another university, it takes high levels of enthusiasm and commitment to organize such research endeavour and to sustain it (Trotman, 2015). Given the benefits reported on in this article, it is surely worth the effort to stimulate 'knowledge-generating' CPD (Borg, 2015) in teachers through projects such as this elsewhere. Such efforts conducted in diverse contexts also need to be researched themselves, e.g. for the psychological benefits they offer, and the results shared with the research community and amongst practitioners in general so that they can then inspire others. Projects such as these seem to have the potential to stimulate growth in teachers' self-efficacy beliefs of various kinds (TSE, GSE and TRE), and interested researchers could perhaps seek such projects out to advance understandings of the inter-connectedness of these beliefs with developing knowledge.

We leave the last word to one of the teacher-researchers in the study, Koray, who has recently described (in an online forum) his experience of growing as a researcher on this project as 'liberating'. Indeed, while we have been drafting accounts of their professional development, the three teacherresearchers have been continuing this, with presentations on their latest research projects to make in the next few weeks and related publications to follow next year.

\section{Acknowledgements}

We would like to thank the teacher-researchers for participating in our study. We would also like to thank anonymous reviewers for their very helpful feedback on an earlier draft.

\section{References}

Allwright, D. and Hanks, J. (2009). The developing language learner. Basingstoke: Palgrave Macmillan.

Atay, D. (2008). Teacher research for professional development. ELT Journal, 62(2), 139-147.

Bandura, A. (1986). Social foundations of thought and action: A social cognitive theory. New York: Prentice-Hall.

Bandura, A. (1997). Self-efficacy: The exercise of control. New York: Freeman.

Berliner, D.C. (1988). The development of expertise in pedagogy. Washington: AACTE Publications.

Borg, S. (2003). Research in the lives of TESOL professionals. TESOL Matters, 13(1), 1-5.

Borg, S. (2009). English language teachers' conceptions of research. Applied Linguistics, 30(3), 358-388.

Borg, S. (2010). Doing good quality research. JACET Journal, 50, 9-13.

Borg, S. (2013). Teacher research in language teaching. Cambridge: CUP. 
Borg, S. (2015). Beyond the workshop: CPD for English language teachers. In S. Borg (ed.), Professional development for English language teachers: perspectives from higher education in Turkey (pp. 5-13). Ankara: British Council, Turkey.

Brown, D.H. (2000). Principles of language learning and teaching (4th ed.). New York: Longman.

Burns, A. (1999). Collaborative action research for English language teachers. Cambridge: CUP.

Cabaroglu, N. (2014). Professional development through action research: Impact on self-efficacy. System, 44, 79-88.

Carrell, P.L. and Eisterhold, J.C. (1983). Schema theory and ESL reading pedagogy. TESOL Quarterly, 17(4), 553-573.

Çelik, Ç. and Dikilitaş, K. (2015). Action research as a professional development strategy. In S. Borg and S. Sanchez (eds). International perspectives on teacher research. Basingstoke: Palgrave.

Calderhead, J. (1988). The development of knowledge structures in learning to teach. In J. Calderhead (Ed.), Teachers' professional learning (pp. 51-64). London: The Falmer Press.

Chacón, C.T. (2005). Teachers' perceived efficacy among English as a foreign language teachers in middle schools in Venezuela. Teaching and Teacher Education, 21(3), 257-272.

Chesnut, S.R. and Burley, H. (2015). Self-efficacy as a predictor of commitment to the teaching profession: A meta-analysis. Educational Research Review. http://dx.doi.org/doi:10.1016/j.edurev.2015.02.001

Cohen, L., Manion, L. and Morrison, K. (2007). Research methods in education (6 $6^{\text {th }}$ ed.). London: RoutledgeFalmer.

Collins, M., Shattell, M. and Thomas, S.P. (2005). An exploration of problematic interviewee behaviors in qualitative research. Western Journal of Nursing Research, 27, 188-199.

Corder, S.P. (1987). Error analysis and interlanguage. Oxford: OUP.

Dikilitaş, K. (ed.). (2012). Teacher-research studies at foreign language school: Inquiries from teacher perspectives, Vol. 1. Ankara: Nobel.

Dikilitaş, K. (ed.). (2013). Teacher-research studies at foreign language school: Inquiries from teacher perspectives, Vol. 2. Ankara: Nobel.

Dikilitaş, K. (ed.). (2014). Professional development through teacher research. İzmir: Gediz University Press.

Dikilitaş, K. (2015). Teacher research for instructors. In S. Borg (ed.), Professional development for English language teachers: perspectives from higher education in Turkey (pp. 27-33). Ankara: British Council, Turkey.

Dikilitaş, K., Smith, R.C. and Trotman, W. (eds.). (2015). Teacher researchers in action. Canterbury, Kent: IATEFL.

Dweck, C.S. (2000). Self-theories: Their role in motivation, personality and development. Philadelphia: Taylor \& Francis.

Geertz, C. (1973). The interpretation of cultures: Selected essays. New York: Basic Books. 
Henson, R.K. (2001). The effects of participation in teacher research on teacher efficacy. Teaching and Teacher Education, 17(7), 819-836.

Henson, R.K., Bennett, D.T., Sienty, S.F. and Chambers, S.M. (2000). The relationship between means-end task analysis and context specific and global self-efficacy in emergency certification teachers: Exploring a new model of teacher efficacy. Paper presented at the annual meeting of the American Educational Research Association, New Orleans.

Holliday, A. (2002). Doing and writing qualitative research. London: Sage.

Jarvis, S. (2001). Research in TESOL: sunset or a new dawn? TESOL Research Interest Section Newsletter 8(2), 1-7.

Kolb, D (1984). Experiential Learning as the Science of Learning and Development. Englewood Cliffs, NJ: Prentice Hall.

Pajares, F.M. (1992). Teachers' beliefs and educational research: Cleaning up a messy construct, Review of Educational Research, 62(3), 307-332.

Schön, D. (1983). The reflective practitioner: How professionals think in action. London: Temple Smith.

Scrivener, J. (1994). Learning teaching. Oxford: Heinemann.

Siwatu, K.O. (2007). Preservice teachers' culturally responsive teaching selfefficacy and outcome expectancy. Teaching and Teacher Education, 23(7), 1086-1101.

Siwatu, K.O. (2011). Preservice teachers' culturally responsive teaching selfefficacy-forming experiences: A mixed methods study. The Journal of Educational Research, 104(5), 360-369.

Skinner, E.A. (1996). A guide to constructs of control. Journal of Personality and Social Psychology, 71, 549-570.

Smith, R. (2014). Supporting teacher research: the work of Kenan Dikilitaş and teachers at Gediz University, Izmir. ELT Research, 29, 16-18.

Smith, R., Connolly, T., and Rebolledo, P. (2014). Teacher research as continuing professional development: a project with Chilean secondary school teachers. In D. Hayes (Ed.), Innovations in the continuing professional development of English language teachers (pp. 111-129). London: British Council.

Smith, R. (2015). Review of 'teacher research in language teaching'. ELT Journal, 69(2), 205-208.

Stake, R.E. (1995). The art of case study research. Thousand Oaks, California: Sage.

Stake, R.E. (2006). Multiple case study research analysis. New York: The Guilford Press.

Thornbury, S. and Watkins, P. (2007). The CELTA course. Cambridge: CUP.

Trotman, W. (2015). The road to Gediz. ELT Research, 30, 16.

Tschannen-Moran, M. and Woolfolk Hoy, A. (2007). The different antecedents of self-efficacy beliefs of novice and experienced teachers. Teaching and Teacher Education, 23(6), 944-956

Tschannen-Moran, M., Woolfolk-Hoy, A. and Hoy, W.K. (1998). Teacher efficacy: Its meaning and measure. Review of Educational Research, 68, 202-248. 
Ur, P. (1996). A course in language teaching. Cambridge: CUP.

Vygotsky, L. (1978). Mind in Society. London: Harvard University Press.

Wheatley, K.F. (2002). The potential benefits of teacher efficacy doubts for educational reform. Teaching and Teacher Education, 18(1), 5-22.

Wheatley, K.F. (2005). The case for reconceptualizing teacher efficacy research. Teaching and Teacher Education, 21(7), 747-766.

Wyatt, M. (2008). Growth in practical knowledge and teachers' self-efficacy during an in-service BA (TESOL) programme. Unpublished PhD dissertation, School of Education, University of Leeds, UK.

Wyatt, M. (2010). An English teacher's developing self-efficacy beliefs in using groupwork. System, 38(4), 603-613.

Wyatt, M. (2011). Teachers researching their own practice. ELT Journal, 65(4), 417-425.

Wyatt, M. (2013). Overcoming low self-efficacy beliefs in teaching English to young learners. International Journal of Qualitative Studies in Education, 26(2), 238-255.

Wyatt, M. (2014a). Towards a re-conceptualization of teachers' self-efficacy beliefs: tackling enduring problems with the quantitative research and moving on. International Journal of Research and Method in Education, 37(2), 166-189.

Wyatt, M. (2014b). Action research on a teacher education programme. ELT Research 29, 5-8.

Wyatt, M. (2015a). Using qualitative research methods to assess the degree of fit between teachers' reported self-efficacy beliefs and their practical knowledge during teacher education. Australian Journal of Teacher Education, 40(1), Art 7, 1-30.

Wyatt, M. (2015b). "Are they becoming more reflective and/or efficacious?" A conceptual model mapping how teachers' self-efficacy beliefs might grow. Educational Review, advance access, first published online 16 July, 2015:

http://www.tandfonline.com/doi/full/10.1080/00131911.2015.1058754 


\section{Appendix 1: Teachers' research efficacy beliefs survey}

\section{Background information}

\begin{tabular}{|l|l|c|}
\hline No. & Questions & Your answer \\
\hline 1 & $\begin{array}{l}\text { How long have you been a teacher? Could you please describe } \\
\text { your teaching experience briefly below? }\end{array}$ & $\begin{array}{c}\text { - years, } \\
\text { - months }\end{array}$ \\
\hline 2 & $\begin{array}{l}\text { How long have you been conducting research at the university? } \\
\text { Could you please describe the research activities you have engaged } \\
\text { in briefly? }\end{array}$ & $\begin{array}{c}\text { — years, } \\
\text { — months }\end{array}$ \\
\hline 3 & $\begin{array}{l}\text { Before you came to the university, did you have prior experience } \\
\text { of conducting research? If so, could you please describe this } \\
\text { briefly? }\end{array}$ & Yes/no \\
\hline 4 & $\begin{array}{l}\text { What education or training have you had in conducting research? } \\
\text { Please briefly outline any received. }\end{array}$ & \\
\hline
\end{tabular}

\section{How self-confident do you feel about doing research?}

Thinking specifically about the research you conduct while a teacher at the university, please answer the following questions.

\begin{tabular}{|c|c|c|}
\hline No. & Item & $\begin{array}{l}\text { Your score } \\
\text { Key: } \\
1=\text { not at all } \\
3=\text { very little } \\
5=\text { to some extent } \\
7=\text { quite a lot } \\
9=\text { a great deal }\end{array}$ \\
\hline 1. & $\begin{array}{l}\text { To what extent can you identify an issue that } \\
\text { needs researching? Why? Please be as specific as } \\
\text { possible } \\
\text { Since you started doing research, has your self- } \\
\text { confidence in this changed? If so, what has helped or } \\
\text { hindered you? }\end{array}$ & $\begin{array}{lllllllll}1 & 2 & 3 & 4 & 5 & 6 & 7 & 8 & 9\end{array}$ \\
\hline 2. & $\begin{array}{l}\text { To what extent can you develop specific research } \\
\text { questions? Why? Please be as specific as possible } \\
\text { Since you started doing research, has your self- } \\
\text { confidence in this changed? If so, what has helped or } \\
\text { hindered you? }\end{array}$ & $\begin{array}{lllllllll}1 & 2 & 3 & 4 & 5 & 6 & 7 & 8 & 9\end{array}$ \\
\hline
\end{tabular}




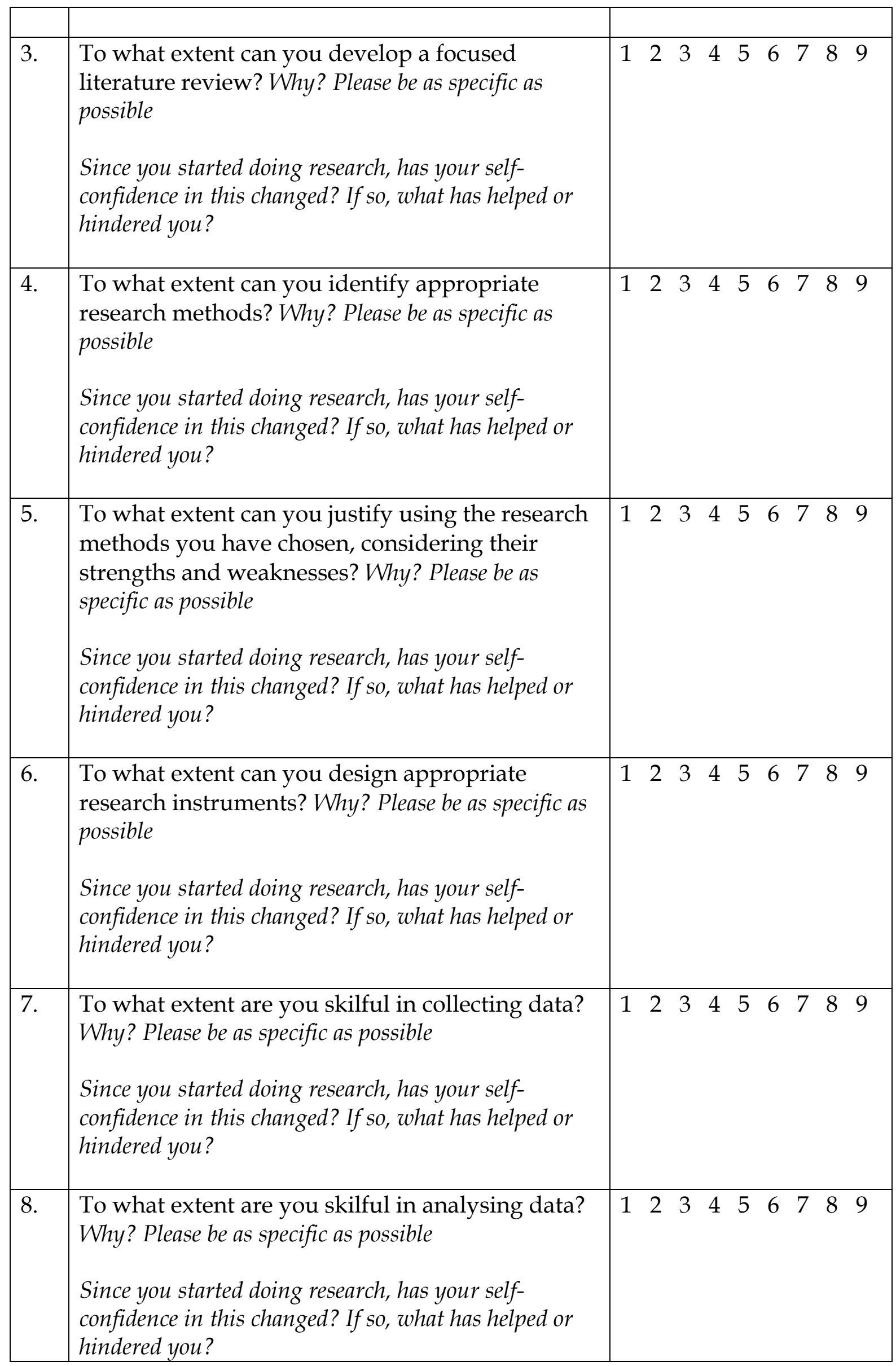




\begin{tabular}{|c|c|c|}
\hline & & \\
\hline 9. & $\begin{array}{l}\text { To what extent can you conduct research in an } \\
\text { ethical way? Why? Please be as specific as possible } \\
\text { Since you started doing research, has your self- } \\
\text { confidence in this changed? If so, what has helped or } \\
\text { hindered you? }\end{array}$ & $\begin{array}{lllllllll}1 & 2 & 3 & 4 & 5 & 6 & 7 & 8 & 9\end{array}$ \\
\hline 10. & $\begin{array}{l}\text { To what extent are you able to produce research } \\
\text { that contributes to knowledge, with implications } \\
\text { for practice? Why? Please be as specific as possible } \\
\text { Since you started doing research, has your self- } \\
\text { confidence in this changed? If so, what has helped or } \\
\text { hindered you? }\end{array}$ & $\begin{array}{lllllllll}1 & 2 & 3 & 4 & 5 & 6 & 7 & 8 & 9\end{array}$ \\
\hline 11. & $\begin{array}{l}\text { To what extent are you able to adopt a critical } \\
\text { stance, constantly questioning your own biases? } \\
\text { Why? Please be as specific as possible } \\
\text { Since you started doing research, has your self- } \\
\text { confidence in this changed? If so, what has helped or } \\
\text { hindered you? }\end{array}$ & $\begin{array}{lllllllll}1 & 2 & 3 & 4 & 5 & 6 & 7 & 8 & 9\end{array}$ \\
\hline 12. & $\begin{array}{l}\text { To what extent are you able to produce coherent } \\
\text { reports of your research, both in oral and written } \\
\text { form? Why? Please be as specific as possible } \\
\text { Since you started doing research, has your self- } \\
\text { confidence in this changed? If so, what has helped or } \\
\text { hindered you? }\end{array}$ & $\begin{array}{lllllllll}1 & 2 & 3 & 4 & 5 & 6 & 7 & 8 & 9\end{array}$ \\
\hline
\end{tabular}

\section{A final question or two...}

How has engaging in research affected your teaching? Has it impacted your selfconfidence in any way or your sense of autonomy? Has it affected the way you work with colleagues? Has it affected your understanding of your learners? Have your learners benefited from your research, and if so, how? Please share your thoughts

Please cite as:

Wyatt, M. \& Dikilitaş, K. (2016). English language teachers becoming more efficacious through research engagement at their Turkish university.

Educational Action Research, 24(4), 550-570.

http:/ / www.tandfonline.com/doi/pdf/10.1080/09650792.2015.1076731 